\title{
Surveillance programs for detection and characterization of emergent pathogens and antimicrobial resistance. Results from the Division of Infectious Diseases, UNIFESP
}

\author{
ARNALDO L. COLOMBO ${ }^{1}$, MARIO JANINI ${ }^{2}$, REINALdO SALOMÃo ${ }^{1}$, EDUARDO A.S. MEDEIROS ${ }^{1}$, \\ SERGIO B. WEY ${ }^{1}$ and ANTONIO C.C. PIGNATARI ${ }^{1}$ \\ ${ }^{1}$ Divisão de Doenças Infecciosas, Departamento de Medicina, Universidade Federal de São Paulo, UNIFESP \\ Rua Botucatu, 740, 04023-062 São Paulo, SP, Brasil \\ ${ }^{2}$ Departamento de Microbiologia, Imunologia e Parasitologia, Universidade Federal de São Paulo, UNIFESP \\ Rua Botucatu, 740, 04023-062 São Paulo, SP, Brasil \\ Manuscript received on July 8, 2008; accepted for publication on May 12, 2009; \\ presented by LUIZ R. TRAVASSOS
}

\begin{abstract}
Several epidemiological changes have occurred in the pattern of nosocomial and community acquired infectious diseases during the past 25 years. Social and demographic changes possibly related to this phenomenon include a rapid population growth, the increase in urban migration and movement across international borders by tourists and immigrants, alterations in the habitats of animals and arthropods that transmit disease, as well as the raise of patients with impaired host defense abilities. Continuous surveillance programs of emergent pathogens and antimicrobial resistance are warranted for detecting in real time new pathogens, as well as to characterize molecular mechanisms of resistance. In order to become more effective, surveillance programs of emergent pathogens should be organized as a multicenter laboratory network connected to the main public and private infection control centers. Microbiological data should be integrated to guide therapy, adapting therapy to local ecology and resistance patterns. This paper presents an overview of data generated by the Division of Infectious Diseases, Federal University of São Paulo, along with its participation in different surveillance programs of nosocomial and community acquired infectious diseases.
\end{abstract}

Key words: emerging infectious diseases, HIV, AIDS, candidemia, antimicrobial resistance, bacteremia, sepsis, nosocomial infectious.

\section{INTRODUCTION}

Since the development of antimicrobial drugs against bacteria, fungi, virus and protozoa, resistance has been a major concern, particularly after the widespread use of antibiotics in clinical settings. Failure of conventional therapy of infectious diseases is obviously responsible for high morbidity and mortality rates in different populations, in addition to the increase of costs of health

In commemoration of the $75^{\text {th }}$ anniversary of Escola Paulista de Medicina / Universidade Federal de São Paulo. Correspondence to: Dr. Arnaldo Lopes Colombo

E-mail: colomboal@terra.com.br assistance, particularly when new and generally highly expensive antimicrobial drugs need to be incorporated with the clinical practice.

Continuous surveillance programs of emergent pathogens and antimicrobial resistance studying clinical isolates representative from different geographic areas are necessary for detecting in real time new pathogens, as well as to characterize molecular mechanisms of resistance. In order to be more effective, surveillance programs should be organized as a multicenter laboratory network connected to the main epidemiological public and private infection control centers, helping the health 
care community to optimize the introduction of effective measures for infection control and prevention.

At the Infectious Diseases Division of the Federal University of São Paulo (UNIFESP), we have organized and/or actively participated in different surveillance programs of bacterial, fungi and viral infections. Three laboratories of our division have been granted international excellence level with important contributions: Special Microbiology Laboratory, Special Micology Laboratory and Retrovirology Laboratory.

\section{SPECIAL MICROBIOLOGY LABORATORY-UNIFESP: SURVEILLANCE PROGRAMS OF NOSOCOMIAL BACTERIAL INFECTIONS}

EPIDEMIOLOGY OF Nosocomial InFECTIONS DUE TO

METHICILLIN-RESISTANT Staphylococcus aureus

Created in 1990, The Special Microbiology Laboratory has been part and/or has organized several multicenter surveillance studies of bacterial resistance, including community acquired and nosocomial infections with more than 50,000 bacterial samples collected from different sites of infection and colonization.

Methicillin-resistant Staphylococcus aureus (MRSA) has been the major nosocomial infections agent since the 80 's of the last century. One of the clinical settings with higher risk of acquiring MRSA infections presenting considerable morbidity and mortality rates are represented by the chronic renal patients under peritoneal or hemodialysis. In São Paulo, we evaluated the epidemiology of colonization and infecton by Staphylococcus aureus in these particular setting of patients by using molecular typing methods (Pignatari et al. 1990, 1991) contributing for the implementation of nosocomial infection control measures at our university hospital, the Hospital São Paulo (Sesso et al. 1998).

At the beginning of the 90's, after conducting an epidemiological study in 8 hospitals of the city of São Paulo, we detected the dissemination of strains with a specific DNA macrorestriction profile generated by pulsed field gel electrophoresis (PFGE) that we named "SP clone". This clone was further identified as the Brazilian Epidemic Clone (BEC), one of the five global major clones that still occurs nowadays in South America (Sader et al. 1994).

The "BEC clone" was well studied in its micro- biology, clinical and epidemiological aspects. We observed a high lethality rate, increasing of costs and time of hospitalization associated with blood stream infections due to this particular pathogen when compared to infections caused by methicillin susceptible strains (Moreira et al. 1998). In addition, we detected in a MRSA-BEC strain a decrease in its phagocytosis and killing by neutrophils and monocytes when compared with the susceptible isolates (Salgado et al. 2004).

Concerns of the scientific and clinical community increased substantially with the likely of dissemination of the BEC clone to the community, particularly among children. A study recently performed with children of the city of Goiania, Brazil, addressed this issue and demonstrated that the dissemination of BEC in this particular population is rare (Lamaro-Cardoso et al. 2007). Lately, investigators performing a molecular characterization of the mec staphylococcal gene cassete (SCCmec) from episodes of community acquired infections found the dissemination of methicillin resistant strains within the community exhibiting highly virulent clones that were not genetically related to the hospital acquired ones, such as the BEC (type III SCCmec) in Brazil. This new phenomenon of dissemination of communityacquired-MRSA is increasing rapidly in the USA and Europe (Stryjewski and Chambers 2008). In order to investigate if this MRSA community acquired infection is occurring in Latin America, we tested a large collection of 6,739 MRSA strains isolated from 1997 to 2006 at clinical centers in Brazil, Chile and Argentina. We observed the introduction of new clones of MRSA, specially the pediatric type IV SCCmec, both at the community and at the hospital. This finding has clinical impact regarding clinical practice once that this new clone is more susceptible to other groups of non beta-lactams antibiotics compared with the BEC clone. In the other hand, they may be more virulent if producing toxins such as the Panton-Valentine leukocidin (S.S. Andrade, unpublished data).

\section{Contributions of the Special Microbiology}

LABORATORY-UNIFESP TO THE SENTRY:

FOCUS IN BRAZIL AND LATIN AMERICA

Considering our expertise in conducting surveillance studies in Brazil, we were invited in 1996 to coordi- 
nate the Latin America branch of one of the most important resistance surveillance programs worldwide, the SENTRY program. The goal of this program is to determine geographic and temporal trends in the antimicrobial susceptibility profiles of the main pathogens causing community and nosocomial infections. The bacterial strains are collected prospectively at hospitals and laboratories enrolled as sentinel centers which are organized in an international surveillance network from five continents, with the coordinator center located at the State of Iowa, USA. In Latin America, several centers have participated in this program, including institutions from Mexico, Venezuela, Chile, Colombia and Brazil (São Paulo, Florianópolis, Porto Alegre and Brasília). Several reports of the SENTRY program have been published through more than 10 years of collaboration. In 2004, we reported the in vitro activity of several antimicrobial agents against more than 20,000 clinical isolates collected from different medical centers in Latin America (Sader et al. 2004). These data have been used to guide empirical therapy and the local implementation of measures for infection control and prevention. Our data supports the conclusion that antimicrobial resistance of Gram-negative bacteria seems to be higher in Latin America as compared to other regions of the world, particularly North America and Europe. Multi-drug resistance among Gram-negative bacilli was particularly observed in Acinetobacter baumannii and Pseudomonas aeruginosa strains. For Pseudomonas aeruginosa, the Brazilians centers exhibited the highest rates of resistance documented worldwide. In addition, the Brazilian rate of Enterobacteriaceae producing expanded spectrum B lactamase (ESBL) was higher than that documented in any other country. On the other hand, vancomycin-resistant enterococci (VRE) and penicillin-resistant pneumococci are less frequently described in Latin America (Jones 2001, Andrade et al. 2003).

The Sentry program has also provided some data on the evaluation of community acquired infections, such as the surveillance of $E$. coli resistance to the antimicrobial group of quinolones in urinary tract infections. This type of information is relevant for establishing concepts of adequacy of empirical therapy in this particular clinical setting (Andrade et al. 2006, Casta- nheira et al. 2007).

\section{Contributions of the Special Microbiology \\ LABORATORY-UNIFESP TO THE CHARACTERIZATION \\ of New Mechanism of GRam-Negative \\ RESISTANCE TO CARBAPENENS}

As previously stated, multidrug resistance among Acinetobacter baumannii and Pseudomonas aeruginosa strains, particularly to the potent group of beta-lactam antibiotics carbapenems, is rising rapidly in Brazil. Invasive infections caused by the both mentioned species of bacteria are usually only susceptible to the antimicrobial group of polymyxins and are responsible for high morbidity and mortality rates among hospitalized patients (Furtado et al. 2007). The mechanism of resistance to carbapenems was originally described as related to the loss of a membrane porine, impairing the transportation of the drug to its target of action. New mechanisms of resistance have been investigated, including the production of metallo-beta-lactamase coded by a gene carried by integrons, as reported since the 90 's in Japan and Italy.

Recently, investigators of our group contributed to the detection and characterization of a new metallobetalactamase gene $b l a_{\mathrm{spm}}$ reponsible for the production of an enzyme that inactivates carbapenems (Toleman et al. 2002). This gene is not carried by integrons, but has been detected in plasmid, allowing a more effective horizontal dissemination among strains of Pseudomonas aeruginosa. In addition, we observed a clonal dissemination of Pseudomonas aeruginosa carrying $b l a_{\mathrm{spm}}$ in medical centers from Brazil (Gales et al. 2003). The rapid identification of carbapenem resistance in these bacteria, particularly from blood stream cultures, is of paramount importance in terms of clinical care. In this way, we recently published a rapid protocol for detection of metallo-beta-lactamases encoding genes by multiplex real-time PCR (Mendes et al. 2007).

\section{SPECIAL MYCOLOGY LABORATORY-UNIFESP: SURVEILLANCE PROGRAMS OF HEMATOGENOUS INFECTIONS DUE TO CANDIDA SPP.}

Candidemia is a growing problem in tertiary care hospitals all over the world where it is commonly observed among patients with long-stay hospitalization who have 
been exposed to antibiotics, immunosuppressive therapy, parenteral nutrition and other invasive medical procedures. Despite all advances in medical practices, hematogenous candidiais is still considered difficult to diagnose, leads to prolonged hospitalization, causes a mortality rate of around $50 \%$ and is a financial burden to health care systems (Colombo et al. 1999, 2006).

The epidemiology of candidemia has been extensively studied in the USA and Europe, but not in most countries of Latin America. Brazil is an exception, with information on the incidence rates of candidemia, risk populations, trends in the species distribution as well as antifungal resistance being recorded over the last ten years (Colombo and Guimaraes 2003, Morgan 2005).

\section{The Burden of CANDIDEMIa IN BRAZILIAN}

TERTIARY CARE HOSPITALS

Recently, Colombo et al. coordinated 2 large laboratory based surveillance studies to evaluate the epidemiology (including incidence rates), microbiology, treatment and outcome of candidemia in Brazilian tertiary care hospitals. One study enrolled 4 large medical centers in the city of São Paulo, and another one enrolled 11 medical centers in 9 different cities in Brazil. In both studies, epidemiological and clinical data were systematically collected by well trained local investigators who were asked to file up case report forms with the aid of a dictionary of terms. Candida isolates collected during the study were all sent to a core laboratory located at the Division of Infectious Diseases - UNIFESP for further identification and antifungal susceptibility testing. Data generated during the two mentioned multicenter laboratory based on surveillance studies showed the incidence rates of candidemia ranging between 1.66 and 2.49/1,000 admissions in Brazilian tertiary care hospitals. These rates are considered 2 to 10 times higher than those documented in the USA and European medical centers (Colombo et al. 2006, 2007).

Although the reasons of a higher incidence of candidemia in Brazil is not completely understood, it could be reasonable to suggest that this fact should be related to differences in resources that are available for medical care and training programs of healthcare workers to assist critically ill patients, as well as a more conservative approach to the administration of empirical antifungal therapies and prophylaxis to patients at high risk for candidemia (Colombo et al. 2007).

In terms of susceptible populations, considering data generated by the mentioned nationwide surveillance of candidemia, $30 \%$ of all patients who developed fungaemia in public tertiary care hospitals in Brazil were represented by pediatric patients, a significantly greater proportion as compared to North American and European studies (Hajjeh et al. 2004, Tortorano et al. 2006). In terms of coexisting exposures, most adult patients with candidemia were represented by patients with diabetis and other organ failures who have been exposed to multiple risk factors including antibiotics, parenteral nutrition, central venous catheterization and other invasive medical procedures. It is worth mentioning that, at the time of the diagnosis of candidemia, $46 \%$ of the patients were admitted at an intensive care unit, and $39 \%$ of all patients had undergone surgery up to 30 days before developing candidemia (Colombo et al. 2006).

Consequences of cutting public funding polices to the health system on the epidemiology of nosocomial rates of bloodstream infections have been scarcely discussed. In order to evaluate if patients treated at hospitals under different levels of financial support exhibit differences in the epidemiology of candidemia, we started a multicenter study to compare 2 public tertiary care hospitals in Brazil with the data generated by 6 private hospitals located in São Paulo (1), Rio de Janeiro (3), Curitiba (1) and Salvador (1). We collected data on the epidemiology (including incidence rates), microbiology, treatment and outcome of candidemia using a web-based case report form, and compared the characteristics of candidemia in patients from public and private hospitals. Preliminary analysis of data collected during this study suggest that incidence rates of candidemia (3.04 vs. $1.04 / 1000$ admissions, $\mathrm{p}<0.01)$, as well as mortality rates $(53 \times 40 \%, \mathrm{p}=0.06)$, were higher in the 2 public tertiary care hospitals than in the 6 private institutions (A.L. Colombo et al., unpublished data).

\section{Species Distribution of CANDida ANd Antifungal} Resistance Related to EPisodes of CANDidemia

Antifungal resistance surveillance programs have been conducted recently by different groups, and there is 
mounting evidence suggesting that the emergence of invasive infections due to Candida non-albicans (CNA) species resistant to fluconazole may be an increasing problem in several medical centers in the world. Fluconazole resistance rates of $C$. glabrata bloodstream isolates range from 7 to $14 \%$ in American hospitals, and from 3.7 to $40 \%$ in European hospitals (Chryssanthou 2001, Diekema et al. 2002, Ostrosky-Zeichner et al. 2003, Hajjeh et al. 2004, Cuenca-Estrella et al. 2005, Tortorano et al. 2006).

Unlike the epidemiology of North Hemisphere countries, there is still a predominance of non-albicans Candida species in Brazil susceptible to fluconazole represented mostly by $C$. parapsilosis and C. tropicalis strains (Colombo et al. 1999, 2006, Antunes et al. 2004, Aquino et al. 2005). According to most series collected in Brazilian medical centers, candidemia due to C. glabrata persists at a low frequency accounting for less than $5 \%$ of the candidemic episodes. Recently, by analyzing the data related to 1000 episodes of candidemia documented in 4 public medical centers throughout a 9-year period, excluding the rising incidence of C. parapsilosis strains from 1995 to 2003 (19\% versus $25 \%, \mathrm{p}=0.03$ ), there were no changes in the distribution pattern of Candida species (da Matta et al. 2007).

In terms of antifungal resistance, most concerns are related to the emergence of non-Candida albicans species resistant to fluconazole, particularly C. glabrata and C. krusei. The Special Mycology Laboratory at the Division of Infectious Diseases-UNIFESP is an active member of the ARTEMIS Global Antifungal Surveillance Program, a worldwide comprehensive surveillance network which uses the CLSI M44-A disk diffusion method with fluconazole discs to capture resistance rates at 134 different laboratories located in 40 countries. Our last report documented the antifungal susceptibility of 205,329 yeast strains against fluconazole tested from June 1997 to December 2005. According to this report, $90.1 \%$ of all Candida isolates tested were susceptible (S) to fluconazole. On the other hand, fluconazole resistance and dose dependent-susceptibility were observed with $30 \%$ and $90 \%$, respectively, of all C. glabrata and C. krusei strains tested (Diekema et al. 2007, Pfaller et al. 2007). In the last 3 years, we have tested more than 2,000 Candida bloodstream isolates from dif- ferent medical centers as part of 3 different multicenter studies. Overall, we found that fluconazole resistance or dose dependent susceptibility occurs in less than $1 \%$ of the $C$. albicans, C. tropicalis and C. parapsilosis strains related to fungaemia. Nevertheless, 8 to $50 \%$ of all C. glabrata bloodstream isolates tested were considered susceptible dose dependent or resistant to fluconazole, depending on the period and medical centers evaluated. This finding is similar to data generated by other groups in Brazil (Colombo et al. 2006, 2007, da Matta et al. 2007).

Molecular Mechanisms of Antifungal Resistance

Several groups have attempted to characterize the molecular mechanisms of antifungal resistance with Candida albicans and some non-Candida albicans strains in Europe and USA. In Latin America, we were the first group to investigate the mechanisms related to azole resistance by testing Candida strains isolated from AIDS patients.

In a collaborative study with Professor Gustavo Goldman from the Faculdade de Ciências Farmacêuticas de Ribeirão Preto, Universidade de São Paulo, we described the molecular mechanisms of fluconazole-resistance by evaluating $C$. albicans strains isolated from 9 different medical centers. The $C$. albicans isolates used in this study represent a collection of 20 strains which were obtained from AIDS patients with oral or esophageal candidiasis who received fluconazole during a period of 6 to 12 months. The entire open reading frame of the ERG11 gene encoding lanosterol $14 \alpha$-demethylase was sequenced from all $C$. albicans isolates. In addition, we evaluated the overexpression of ERG11 and several genes encoding efflux pumps for azoles by using a quantitative real-time RT-PCR (Goldman et al. 2004)

After screening all resistant $C$. albicans strains, we found the presence of point mutations in the ERG11 gene, overexpression of ERG11, and genes encoding efflux pumps such as CDR and MDR, as measured by quantitative real-time RT-PCR. Several fluconazole-resistant strains had multiple mechanisms of resistance. A total of 4 mutations previously described, Y132F, K143R, E266D, and V437I, were identified among the strains, while some isolates contained more than one mutation (Goldman et al. 2004). 
The mechanisms of azole resistance found in the Brazilian collection of $C$. albicans strains resistant to fluconazole are similar to the results described to date by other groups. In the case of $C$. albicans strains, the fluconazole-resistant phenotype is usually secondary to the coexistence of multiple mechanisms of resistance. Of note, new triazoles have been developed, with the aim of avoiding fluconazole cross resistance. However, cross resistance to voriconazole and posaconazole has been extensively reported with $C$. glabrata and C. albicans strains (Sanglard et al. 1996, Perea et al. 2001, Sanglard and Odds 2002, Kanafani and Perfect 2008).

\section{THE BURDEN OF SEPSIS IN BRAZIL AND SOME STRATEGIES TO DECREASE THE ASSOCIATED CRUDE MORTALITY}

The high incidence of bloodstream infections and sepsis has been continuously evaluated in our Institution by Salomão et al. Between 1985 and 1986, the incidence rate of blood stream infections at the Hospital São Paulo - Universidade Federal de São Paulo, was 21.7 episodes by 1000 admittances, with a crude mortality rate of $33.4 \%$ (Salomão et al. 1992, 1993). A new survey performed at the same institution in 2004 demonstrated that the incidence rate of BSI increased to 26.8 per 1000 admissions exhibiting overall mortality rate of 44\% (Segovia, Pereira and Salomão, personal communication). The increasing incidence of nosocomial sepsis has been discussed by different groups in the USA, where a large study showed a substantial increase of BSI caused by bacteria and fungi along the last 20 years (Martin et al. 2003).

Considering the lack of sensitivity of blood cultures, it is reasonable to suggest that laboratory based surveillance studies may underestimate the true incidence rates of BSI and sepsis. Recently, a Brazilian multicenter surveillance of sepsis was conducted in 5 intensive care units in São Paulo using as inclusion criteria laboratory and clinical data for case definition. This study (BASES - Brazilian Sepsis Epidemiological Study) was conducted by Silva et al. between may 2001 and January 2002, obtaining incidence artes of 57.9 episodes of sepsis per 1000 pacients-day, or 30.5 episodes per 100 admissions. The crude mortality rates of patients with sepsis, severe sepsis and septic shock were $34.7 \%, 47.3 \%$ and $52.2 \%$, respectively (Silva et al. 2004).

The burden of sepsis in the USA was evaluated by a population-based multicenter surveillance study conducted by Martin et al. (2003) including the evaluation of all hospital admissions between 1979 and 2000 . During this study, it was possible to conclude that incidence rates of sepsis in the USA raised from 82.7 episodes/100,000 inhabitants in 1979 to 240.4 episodes/100,000 habitants in 2000 (Martin et al. 2003).

In order to decrease the crude mortality of sepsis, including the concerns with multiresistant pathogens, we have targeted to main aspects: the challenge to use appropriate antimicrobial therapy, and the use of strategies to prevent blood stream infections associated with central venous catheter.

The impact of appropriate therapy in the outcome of BSI was clearly demonstrated some decades ago. We have found that appropriateness of antimicrobial therapy, which happen when the bacteria is susceptible to the antimicrobial administered, has a profound impact on survival rates of patients with blood stream infection and sepsis. Overall mortality was $33.4 \%$ and it could be as low as $21 \%$ in patients receiving appropriate therapy, and as high as $57.1 \%$ in those receiving inappropriate therapy. Interestingly, patients who received inappropriate therapy and were administered appropriate therapy thereafter based on cultures results or lack of clinical responses had intermediate mortality (34.1\%). However, changing antibiotics in patients already with septic shock did not improve outcomes (Salomão et al. 1993). There is increasing evidence that the delay in initiating the antimicrobial therapy has profound impact in mortality. Kumar et al. showed that the duration of hypotension before initiation of effective antimicrobial therapy is the critical determinant of survival in human septic shock (Kumar et al. 2006).

A relevant aspect to be mentioned and monitored is that nosocomial acquired primary bloodstream infections are mainly associated with central venous catheter (CVC-BSI). In a multicenter study, we found increased device-associated nosocomial infections, including CVC-BSI, in Intensive Care Units from developing countries, as compared to the USA and Europe (Rosenthal et al. 2006). We succeed to reduce the rates 
of central vascular catheter-associated bloodstream infections in an adult intensive care unit by using education and performance feedback (Salomão et al. 2005) and reached infections rates similar to the developed countries by switching from an open intravenous infusion system to a closed system (Salomão et al. 2006).

\section{RETROVIROLOGY LABORATORY-UNIFESP: SURVEILLANCE PROGRAMS OF HIV-1 ESCAPE AND RESISTANCE}

Viruses are ubiquitous and the most prevalent biological entity on the planet (Angly et al. 2006, Koonin et al. 2006). However, viruses have constantly to adapt to selective pressures offered by the environment where they propagate. Some of these pressures are not present in nature, such as the pressure exerted by antiretroviral drugs, while others are represented by the host immune response (Bailey et al. 2004). Viruses employ many strategies to escape host defenses or other pressures. Viral evasion strategies enable the virus to avoid recognition by the immune response by changing its epitopes, to interfere with cellular immune responses by disabling peptide presentation, to interfere with immune function by secreting viral encoded cytokines or blocking apoptosis, and to interfere with antiviral drug activity by incorporating drug resistance mutations (Domingo 1997, Vossen et al. 2002, Alcami 2003, Peterlin and Trono 2003, Clavel and Hance 2004, Leslie et al. 2004, Smith 2004, Manrubia et al. 2005, Telenti 2005, MartinezPicado et al. 2006, Schneidewind et al. 2007). Sophisticated DNA viruses have a greater genetic background that allows them to make use of different escape routes, including viral mimicry by incorporation of cellular genes into their genomes (Chaston and Lidbury 2001, Alcami 2003). RNA viruses have smaller genomes and, due to their highly mutation rates, they cannot extend their genomes beyond a limit, being unable to incorporate new and different coding capacities into their genomes (Domingo et al. 1996, 2001, 2005, Domingo 1997, Chaston and Lidbury 2001). RNA virus relay basically on genetic diversification to escape elimination by host defenses or chemical pressures. Diversification gives rise to viral variants with increased resistance. Acquisition of resistance leads to diminished viral fitness (Bleiber et al. 2001, Buckheit 2004, Smith
2004). Viral fitness is generally accepted as the relative ability of a virus to replicate in a defined environment, and is used to describe the viral replication potential in the absence of the selective pressure that originated resistance.

\section{HIV-1 AND GENETIC DIVERSITY}

\section{Global diversity}

Almost 30 years since the first cases of the acquired immunodeficiency syndrome (AIDS), our power to manage infected patients or to reach an effective control of the AIDS pandemic remains limited (Rambaut et al. 2004). According to the 2007 UNIAIDS report, there are over 30 million people living with HIV today. Although HIV global prevalence has leveled off, and the number of new infections has decreased, 2.5 million individuals acquired HIV infection and 2.1 million died of AIDS in 2007. AIDS is among the leading causes of death globally and remains the primary cause of death in Africa (www.uniaids.org). HIV strains are divided into two types, HIV-1 and HIV-2. HIV-1 strains are responsible for the global epidemic drive and are classified in Groups, M, N, and O. Group M encompasses 9 genetic subtypes and more than 40 circulating recombinant forms (CRF) (www.hiv.lanl.gov). HIV-1 global distribution is complex and dynamic, with regional epidemics harboring only a subset of the global diversity. HIV-1 strains differ enormously in terms of global prevalence. 6 viral lineages account for the majority of HIV-1 infections: HIV-1 subtypes A, B, C, D, and two of the CRFs, CRF01-AE and CRF02_AG, respectively. Many of the known subtypes and recombinant forms are currently rare in the epidemic. Groups $\mathrm{O}$ and $\mathrm{N}$ are rare in the pandemic (McCutchan et al. 2004, Kijak and McCutchan 2005, Sa Filho et al. 2005, De Sa Filho et al. 2006, McCutchan 2006, Sanabani et al. 2006, Taylor et al. 2008).

\section{HIV-1 SUbTYPES IN BRAZIL}

The HIV-1 Brazilian epidemic shows a heterogeneous distribution of HIV-1 subtypes and recombinants ( $\mathrm{Sa}$ Filho et al. 2005, De Sa Filho et al. 2006). The most prevalent strains belong to subtype B and were the first introduced in the country in the 1970s. Subtype F strains 
appeared in the 1980s and always accounted for not much than $10 \%$ of all infections. More recently, BF recombinants are gaining ground even surpassing the number of subtype $\mathrm{F}$ infections. Subtype $\mathrm{C}$ strains result from a later introduction and are prevalent in Southern Brazil. Besides plain subtypes, a number of CRFs, have already been identified in Brazil, but their impact on the epidemic is still not clarified (www.hiv.lanl.gov).

\section{INTRAHOST VIRAL DIVERSITY}

In an individual, HIV-1 maintains a rapid evolution pace resulting from high mutation rates, large population sizes, accelerated replication dynamics, and high recombination frequencies. As a result, HIV populations correspond to a swarm of mutants harboring different mutations, and can be referred to as a quasispecies (Domingo 1985). Quasispecies arise from a balance between mutation and natural selection, originating a population of variant viruses. Viruses in a quasispecies cannot be seen as independent entities, but as linked by mutational couplings, with the entire distribution forming a cooperative community that evolves as a single unit (Duarte et al. 1994, Domingo et al. 1996, 1998, 2001, 2005, 2006, Domingo 1997, Holmes and Moya 2002, Jenkins et al. 2002). In a quasispecies, natural selection is no longer directed toward the single fittest variant, but instead acts on the whole mutant distribution. Viral mutant distributions may promptly adapt to new selective pressures due to high mutation rates.

\section{ESCAPE AND RESISTANCE}

\section{Escape}

The genetic background of different individuals influences their susceptibility to HIV-1 infection and disease progression. Differences on viral susceptibility have been attributed to specific HLA types, chemokines and chemokine receptor polymorphism. More recently, 2 cellular proteins, APOBEC3G and TRIM5, have been described as additional antiviral components of the innate immunity (Sheehy et al. 2002) HIV-1 has evolved strategies against the action of both proteins.

Antibodies are important elements of the immune response and succeed in controlling several viral infections. However, HIV-1 is able to replicate continuously in the presence of a vigorous antibody response. The HIV-1 genome encodes two envelope glycoproteins: the transmembrane gp41 anchors the Env complex in the viral envelope and mediates fusion with the host cell membrane, while the surface gp120 interacts with cellular receptors. HIV-1 gp120 is heavily glycosylated and contains 5 "hypervariable" domains, V1 to V5. HIV1 envelope proteins avoid neutralizing antibody by a number of different strategies. Mechanisms of humoral escape include: hiding of critical neutralizing epitopes, extension of gp120 variable loops, conformational protection of viral receptor binding motifs, and extensive glycosylation of envelope surface proteins. It has been demonstrated that acutely infected patients produce NAbs against autologous virus within months of seroconversion (Albert et al. 1990, Tremblay and Wainberg 1990, Richman et al. 2003, Wei et al. 2003, Frost et al. 2005), but although the early produced NAbs reach fairly high titers, escape mutants are rapidly selected due to the ongoing viral replication (Richman et al. 2003, Wei et al. 2003). It also has been shown that chronically HIV-1 infected patients develop NAbs against earlier viral isolates, but they fail to neutralize contemporaneous virus (Albert et al. 1990, Tremblay and Wainberg 1990, Skrabal et al. 2005).

Cytotoxic T-lymphocytes (CTL) are important against HIV-1 (Smith 2004, Betts et al. 2006). CTL destroys HIV infected cells upon recognizing viral peptides bound to class I major histocompatibility complex (MHC) molecules. Different MHC alleles bind viral peptides with distinct affinities. MHC alleles, which bind particular viral peptides strongly, often result in vigorous cellular responses against those viral epitopes. Avoidance of cellular responses results in replicative advantages. Evasion of CTL targeting involves mutations within and around recognized epitopes, and results in the lack of peptide binding to the Class I MHC grove, or non-recognition by the CTL T cell receptor, or interference with peptide processing (Phillips et al. 1991, Goulder et al. 1997, Price et al. 1997, Smith 2004). CTL escape mutations are associated with increased viral loads and rapid disease progression (Koenig et al. 1995, Borrow et al. 1997, Goulder et al. 1997). However, mutations associated with CTL escape cause significant viral fitness costs. Fitness costs correlated with CTL 
evasion have been demonstrated in patients carrying the $\mathrm{B}^{*} 57, \mathrm{~B} * 5801$, and $\mathrm{B} * 27$ HLA alleles (Friedrich et al. 2004, Smith 2004, Martinez-Picado et al. 2006, Crawford et al. 2007).

\section{Resistance}

Several classes of drugs are used against HIV-1 and target different steps of the viral replication cycle. They include: nucleoside analogues, which act as DNA synthesis terminators inhibiting reverse transcription; nonnucleoside reverse-transcriptase antagonists, which directly inhibit reverse transcriptase; protease inhibitors interfering with viral maturation; entry inhibitors including CCR5 blocking agents and fusion inhibitors, designed to halt HI1 penetration into permissible cells; and the newly approved integrase inhibitor that acts by blocking HIV-1 integration into the cellular genome (Lucas et al. 1999, Dybul et al. 2002, Kress 2004, Kuritzkes 2004, Luber 2005, Piacenti 2006, Evering and Markowitz 2007, Opar 2007, Hendrickson et al. 2008, Lagnese and Daar 2008, Laurence 2008, Strizki 2008). Antiretroviral drugs are used in different combinations, usually of 3 antiretroviral drugs, with 2 nucleoside analogues and either a protease or a nonnucleoside inhibitor, with regimens starting to feature entry inhibitors when HIV infection has not been controlled by other drug combinations (http://www.aidsinfo.nih.gov/ ContentFiles/AdultandAdolescentGL.pdf. Accessed April 19, 2008).

The simultaneous use of different drugs is known as highly active antiretroviral therapy (HAART). The goal of HAART is to achieve and maintain viral loads below 50 copies/mL. Suppression below this level is associated with treatment success, helps immunological restoration, and difficults the onset of viral resistance. The development of drug resistance requires the concurrence of 2 factors: antiretroviral drug exposure and ongoing viral replication. Initially thought as a cure for HIV infection (Perelson et al. 1996), today we know that HAART cannot eradicate HIV-1 (Wong et al. 1997, Siliciano 1999, Siliciano and Siliciano 2000, Bailey et al. 2006). Undoubtedly, HAART has increased the quality of life for HIV-1 infected persons. However, limitations of HAART started to appear by the identification of latent HIV-1 reservoirs (Blankson et al. 1999, 2002, Siliciano 1999, Siliciano and Siliciano
2000, 2004, Bailey et al. 2006). These reservoirs act as viral archives ready to replenish the pool of replicating virus. Although drug therapy is efficient at controlling plasma viral levels, viruses in reservoirs are not targeted by the drugs. Because viral recombination was not taken into account, resistance mutations were thought to accumulate in distinct genomes in an ordered fashion (Molla et al. 1996). Recombination allows the virus to exchange resistance mutations in a nonlinear fashion, leading to rapid evolution leaps of resistant mutants, even from different reservoirs (Morris et al. 1999, Zhuang et al. 2002, Levy et al. 2004, Charpentier et al. 2006, Nora et al. 2007). Finally, seminal studies from patients undergoing HAART wrongly concluded that the virus was not experiencing evolution if viral loads were undetectable (Wong et al. 1997, Finzi and Siliciano 1998). Although not detectable in the plasma, ongoing viral replication in localized niches would inevitably lead to the incorporation of mutations, and some would result in virus with diminished drug susceptibility (Chun et al. 1999, Martinez-Picado et al. 2000). Evolution of drug resistance reduces our ability to control HIV-1. Drug therapy failure results from the accumulation of drug resistance mutations. The genetic barrier for resistance varies from drug to drug. Resistance to some drugs, as nonnucleoside inhibitors, may happen after just a brief exposure to the drug. Conversely, resistance to protease or nucleoside inhibitors generally requires the selection of a combination of mutations (Clavel and Hance 2004, Nettles et al. 2004, Lucas 2005, Wood et al. 2005, Taylor et al. 2008). Mutation in both protease and reverse transcriptase may lead to a reduction in viral fitness, with either enzyme displaying a profound impairment (Bleiber et al. 2001, Buckheit 2004). Resistance to HIV-1 fusion inhibitors is also associated with impaired fitness, while resistance to nonnucleoside reverse transcriptase inhibitors has a less evident effect on viral replication (Schmit et al. 1996, Chen et al. 2005). Acquisition of viral drug resistance generally follows a common series of events: the initial selection of drug-resistance mutations causing viral fitness reductions and, subsequently, the introduction of compensatory mutations enabling the virus to recover fitness (Bleiber et al. 2001, Buckheit 2004).

Drug-resistant mutations are detected in drugnaïve patients (Ribeiro et al. 1998, Brumme et al. 2007, 
Smith et al. 2007, Sucupira et al. 2007, Little et al. 2008), but recent data suggest that the prevalence of drug-resistant HIV in newly diagnosed patients may have leveled off at approximately $10 \%$ over the past several years (Kuritzkes 2007). However, existence of HIV drug resistance prior to the initiation of antiretroviral therapy can be a major impediment to successful treatment outcomes (Ribeiro et al. 1998, Daar 2007, Metzner et al. 2007). Data on resistance patterns for new drugs and new drug classes are beginning to emerge. All 3 new categories of antiretroviral agents (chemokine receptor inhibitors, second-generation nonnucleosides, and integrase inhibitors) have shown vulnerability to drug resistance (Kuritzkes 2007). Moreover, minority HIV-1 variants that may not be detected by current resistance tests may have an impact on treatment, limiting future therapeutic approaches (Metzner 2006, Daar 2007).

\section{HIV-1 RESISTANCE IN BRAZIL}

In 1996 the Brazilian Government approved a Federal law that established an universal access to HAART for citizens living with HIV-1 (www.aids.gov.br). There are approximately 185,000 HIV-1 infected individuals receiving HAART today in Brazil (www.aids.gov.br). Although introduction of HAART has certainly slowed the disease progression among infected people, some of its consequences are the emergence of viral resistance and the transmission of resistant strains. HIV-1 resistance mutations, to at least one class of drugs, can be detected in a high percentage of the treatment experienced by Brazilian individuals (Cavalcanti et al. 2007, De Sa Filho et al. 2008), but the levels of transmitted resistance are comparable to the ones observed in Europe and in the United States (Brindeiro et al. 2003). However, 2 studies indicated much higher primary resistance levels in the coastal cities of Santos and Salvador (Pedroso et al. 2007, Sucupira et al. 2007). Because Brazil was a pioneer in Government sponsored broad drug distribution, there is a constant need to survey HIV1 resistance levels in treatment naïve and experienced individuals living in the country.

\section{FUTURE PERSPECTIVES}

We are currently conducting a new nationwide surveillance program of nosocomial blood stream infections at 15 medical centers located in different regions of Brazil named SCOPE Brazil (Surveillance and Control of Pathogens of Epidemiological Importance). This program will combine for the first time the efforts of all investigators of our Divison interested in the evaluation of nosocomial bloodstream infections, regardless of the pathogen that causes the disease. We believe that this is a compreensive and effective program that will contribute to more adequate infection control and antimicrobial use of policies in Brazil.

In addition, with the collaboration of Marcio Nucci from the Federal University of Rio de Janeiro, we are establishing the Latin American Candidemia Network, a group of 12 investigators that will conduct a laboratory based surveillance study of candidemia involving 24 medical centers within 9 different countries in Latina America.

With respect to HIV infection, considering the universal access of anti-retroviral drugs in Brazil, it is mandatory to constantly monitor HIV resistance in our population. Our Division is currently involved in checking resistance levels in groups of recently infected patients living in different areas of the country. We have a number of ongoing countrywide collaborations that allow us to collect samples from various locations. Studies like this one are helping us to gauge the primary rate of HIV resistance in Brazil. We are also addressing the stability of drug resistance mutations in naïve patients that acquired the virus from drug experienced patients. Furthermore, we are conducting a series of studies on APOBEC3s polymorphisms encountered in the infected Brazilian population, and investigating how they influence the levels of hypermutation on the viral genome. Finally, we are also constantly surveying the HIV-1 subtype distribution in the country monitoring HIV-1 propagation in Brazil. We were the first group identifying not only one, but two HIV-1 Circulating Recombinant Forms in the Brazilian epidemic.

\section{RESUMO}

Várias alterações epidemiológicas ocorreram no perfil das doenças infecciosas hospitalares e comunitárias nos últimos 25 anos. Mudanças sociais e demográficas possivelmente relacionadas com esse fenômeno incluem o rápido crescimento populacional, o aumento da migração urbana e deslocamento 
através de fronteiras internacionais por turistas e imigrantes, alterações nos habitats de animais e artrópodes que transmitem doença assim como o aumento no número de pacientes com deficiências nas respostas de defesa. Os programas contínuos de vigilância de patógenos emergentes e resistência antimicrobiana são necessários para a detecção em tempo real de novos patógenos assim como para caracterizar mecanismos moleculares de resistência. Para serem mais efetivos, os programas de vigilância dos patógenos emergentes devem ser organizados em uma rede de laboratórios multicêntricos ligados aos principais centros de controle de infecções, públicos e privados. Os dados microbiológicos devem ser integrados a guias terapêuticos adaptando práticas terapêuticas à ecologia local e aos padrões de resistência. O artigo apresenta uma revisão dos dados gerados pela Disciplina de Infectologia, Universidade Federal de São Paulo, contemplando sua participação nos diferentes programas de vigilância de doenças infecciosas hospitalares e adquiridas na comunidade.

Palavras-chave: doenças infecciosas emergentes, HIV, AIDS, candidemia, resistência antimicrobiana, bacteremia, sepsia, infecções hospitalares.

\section{REFERENCES}

Albert JB, Abrahamsso K, Nagy E, Aurelius H, Gaines G. Nystrom And Fenyo EM. 1990. Rapid development of isolate-specific neutralizing antibodies after primary HIV-1 infection and consequent emergence of virus variants which resist neutralization by autologous sera. AIDS 4: 107-112.

AlCAMi A. 2003. Viral mimicry of cytokines, chemokines and their receptors. Nat Rev Immunol 3: 36-50.

Andrade SS, Jones RN, Gales AC and Sader HS. 2003. Increasing prevalence of antimicrobial resistance among Pseudomonas aeruginosa isolates in Latin American medical centres: 5 year report of the SENTRY Antimicrobial Surveillance Program (1997-2001). J Antimicrob Chemother 52: 140-141.

Andrade SS, Sader HS, Jones RN, Pereira AS, PignATARI AC AND GALES AC. 2006. Increased resistance to first-line agents among bacterial pathogens isolated from urinary tract infections in Latin America: time for local guidelines? Mem Inst Oswaldo Cruz 101: $741-748$.

ANGLY FE ET AL. 2006. The marine viromes of four oceanic regions. PLoS Biol 4(11): e368.

Antunes AG, Pasqualotto AC, Diaz MC, D’AzeVEdo PA AND SEvero LC. 2004. Candidemia in a Brazilian tertiary care hospital: species distribution and antifungal susceptibility patterns. Rev Inst Med Trop São Paulo 46(5): 239-241.

AQuino VR, Lunardi LW, GOLdANi LZ AND BARTH AL. 2005. Prevalence, susceptibility profile for fluconazole and risk factors for candidemia in a tertiary care hospital in southern Brazil. Braz J Infect Dis 9(5): 411-418.

Bailey JJ, Blankson N, Wind-Rotolo M AND SiliCIANO RF. 2004. Mechanisms of HIV-1 escape from immune responses and antiretroviral drugs. Curr Opin Immunol 16: 470-476.

BAILEY JR ET AL. 2006. Residual human immunodeficiency virus type 1 viremia in some patients on antiretroviral therapy is dominated by a small number of invariant clones rarely found in circulating CD4+ T cells. J Virol 80: 6441-6457.

BETTS MR ET AL. 2006. HIV nonprogressors preferentially maintain highly functional HIV-specific CD8+ T cells. Blood 107: 4781-4789.

Blankson J, Persaud D and Siliciano RF. 1999. Latent reservoirs for HIV-1. Curr Opin Infect Dis 12: 5-11.

Blankson JN, Persaud D And Siliciano RF. 2002. The challenge of viral reservoirs in HIV-1 infection. Annu Rev Med 53: 557-593.

Bleiber G, Munoz M, Ciuffi A, Meylan P And TELENTI A. 2001. Individual contributions of mutant protease and reverse transcriptase to viral infectivity, replication, and protein maturation of antiretroviral drugresistant human immunodeficiency virus type 1 . J Virol 75: 3291-3300.

BORROW P ET AL. 1997. Antiviral pressure exerted by HIV1-specific cytotoxic $\mathrm{T}$ lymphocytes (CTLs) during primary infection demonstrated by rapid selection of CTL escape virus. Nat Med 3: 205-211.

BRINDEIRO RM ET AL. 2003. Brazilian Network for HIV Drug Resistance Surveillance (HIV-BResNet): a survey of chronically infected individuals. AIDS 17: 1063-1069.

Brumme CJ, Harrigan PR, Preston EC, Dong WW, Wynhoven B, Murphy C And Montaner JS. 2007. Transmission of drug-resistant HIV-1 from an infecte individual to a caregiver. Antivir Ther 12: 1139-1144.

BUCKHEIT RW JR. 2004. Understanding HIV resistance, fitness, replication capacity and compensation: targeting viral fitness as a therapeutic strategy. Expert Opin Investig Drugs 13: 933-958.

Castanheira M, Pereira AS, Nicoletti AG, PignaTARI AC, BARTh AL and Gales AC. 2007. First report of plasmid-mediated qnrA1 in a ciprofloxacin-re- 
sistant Escherichia coli strain in Latin America. Antimicrob Agents Chemother 51: 1527-1529.

Cavalcanti Am, Lacerda HR, Brito AM, Pereira S, Medeiros D and Oliveira S. 2007. Antiretroviral resistance in individuals presenting therapeutic failure and subtypes of the human immunodeficiency virus type 1 in the Northeast Region of Brazil. Mem Inst Oswaldo Cruz 102: 785-792.

Charpentier C, Nora T, Tenaillon O, Clavel F and HANCE AJ. 2006. Extensive recombination among human immunodeficiency virus type 1 quasispecies makes an important contribution to viral diversity in individual patients. J Virol 80: 2472-2482.

Chaston TB And Lidbury BA. 2001. Genetic 'budget' of viruses and the cost to the infected host: a theory on the relationship between the genetic capacity of viruses, immune evasion, persistence and disease. Immunol Cell Biol 79: 62-66.

Chen R, Yokoyama M, Sato H, Reilly C and ManSKY LM. 2005. Human immunodeficiency virus mutagenesis during antiviral therapy: impact of drug-resistant reverse transcriptase and nucleoside and nonnucleoside reverse transcriptase inhibitors on human immunodeficiency virus type 1 mutation frequencies. J Virol 79: 12045-12057.

Chryssanthou E. 2001. Trends in antifungal susceptibility among Swedish Candida species bloodstream isolates from 1994 to 1998: comparison of the E-test and the Sensititre YeastOne Colorimetric Antifungal Panel with the NCCLS M27-A reference method. J Clin Microbiol 39: 4181-4183.

Chun TW, DAVEY RT JR, ENGEl D, LANE HC AND FAUCI AS. 1999. Re-emergence of HIV after stopping therapy. Nature 401(6756): 874-875.

Clavel F and Hance AJ. 2004. HIV drug resistance. N Engl J Med 350: 1023-1035.

Colombo AL and Guimaraes T. 2003. [Epidemiology of hematogenous infections due to Candida spp]. Rev Soc Bras Med Trop 36: 599-607.

Colombo AL, Nucci M, Salomao R, Branchini ML, Richtmann R, Derossi A And Wey SB. 1999. High rate of non-albicans candidemia in Brazilian tertiary care hospitals. Diagn Microbiol Infect Dis 34(4): 281-286.

Colombo AL, Nucci M, Park BJ, Nouer SA, ArThington-Skaggs B, DA Matta DA, WARnock D AND Morgan J. 2006. Epidemiology of candidemia in Brazil: a nationwide sentinel surveillance of candidemia in eleven medical centers. J Clin Microbiol 44: 28162823.
Colombo Al, Guimaraes T, Silva LR, De Almeida Monfardini LP, Cunha AK, Rady P, Alves T AND RosAS RC. 2007. Prospective observational study of candidemia in São Paulo, Brazil: incidence rate, epidemiology, and predictors of mortality. Infect Control Hosp Epidemiol 28: 570-576.

CRAWFORd H ET AL. 2007. Compensatory mutation partially restores fitness and delays reversion of escape mutation within the immunodominant HLA-B*5703-restricted Gag epitope in chronic human immunodeficiency virus type 1 infection. J Virol 81: 8346-8351.

Cuenca-Estrella M et AL. 2005. In vitro susceptibilities of bloodstream isolates of Candida species to six antifungal agents: results from a population-based active surveillance programme, Barcelona, Spain, 2002-2003. J Antimicrob Chemother 55: 194-199.

da Matta DA, de Almeida LP, Machado AM, Azevedo AC, Kusano EJ, Travassos NF, Salomao R AND COLOMBo AL. 2007. Antifungal susceptibility of 1000 Candida bloodstream isolates to 5 antifungal drugs: results of a multicenter study conducted in São Paulo, Brazil, 1995-2003. Diagn Microbiol Infect Dis 57: 399404.

DAAR ES. 2007. Incorporating novel virologic tests into clinical practice. Top HIV Med 15(4): 126-129.

De Sa Filho DJ, Sucupira MC, Caseiro MM, Sabino EC, DiAZ RS AND JANINI LM. 2006. Identification of two HIV type 1 circulating recombinant forms in Brazil. AIDS Res Hum Retroviruses 22: 1-13.

De Sa Filho DJ, Da Silva Soares M, Candido V, Gagliani LH, Cavaliere E, Diaz RS and Caseiro MM. 2008. HIV Type 1 pol Gene Diversity and Antiretroviral Drug Resistance Mutations in Santos, Brazil. AIDS Res Hum Retroviruses 24: 347-353.

Diekema DJ, Messer SA, Brueggemann AB, CoffMAN SL, Doern GV, Herwaldt LA ANd Pfaller MA. 2002. Epidemiology of candidemia: 3-year results from the emerging infections and the epidemiology of Iowa organisms study. J Clin Microbiol 40: 1298-1302.

Diekema DJ, Messer SA, Hollis RJ, Boyken LB, Tendolkar S, Kroeger J and Pfaller MA. 2007. Evaluation of Etest and disk diffusion methods compared with broth microdilution antifungal susceptibility testing of clinical isolates of Candida spp. against posaconazole. J Clin Microbiol 45: 1974-1977.

Domingo E. 1985. The quasispecies (extremely heterogeneous) nature of viral RNA genome populations: biological relevance - a review. Gene 40: 1-8. 
DOMINGO E. 1997. Rapid evolution of viral RNA genomes. J Nutr 127(5 Suppl): 958S-961S.

Domingo E, Escarmis C, Sevilla N, Moya A, Elena SF, Quer J, Novella IS AND Holland JJ. 1996. Basic concepts in RNA virus evolution. FASEB J 10: 859-864.

DOMIngo E, BARANOWSKi E, RUIZ-JARABo CM, MARTIN-HERnANDEZ AM, SAIZ JC AND ESCARMis C. 1998. Quasispecies structure and persistence of RNA viruses. Emerg Infect Dis 4: 521-527.

Domingo e, Mas A, Yuste e, Pariente N, Sierra S, GUTIERREZ-Riva M AND MENENDEZ-ARIAs L. 2001. Virus population dynamics, fitness variations and the control of viral disease: an update. Prog Drug Res 57: $77-115$.

Domingo E, Gonzalez-Lopez C, Pariente N, AiraKSINEN A AND EsCARMIS C. 2005. Population dynamics of RNA viruses: the essential contribution of mutant spectra. Arch Virol Suppl 19: 59-71.

Domingo E, Martin V, Perales C, Grande-Perez A, GARCIA-ARriaZA J, AND ARIAS A. 2006. Viruses as quasispecies: biological implications. Curr Top Microbiol Immunol 299: 51-82.

DUARTE EA ET AL. 1994. RNA virus quasispecies: significance for viral disease and epidemiology. Infect Agents Dis 3: 201-214.

Dybul M, Fauci AS, Bartlett JG, Kaplan JE AND PAU AK. 2002. Guidelines for using antiretroviral agents among HIV-infected adults and adolescents. Ann Intern Med 137(5 Pt 2): 381-433.

EVERING TH AND MARKOWITZ M. 2007. Raltegravir (MK0518): an integrase inhibitor for the treatment of HIV-1 Drugs Today (Barc) 43: 865-877.

FinZI D AND SILICIANO RF. 1998. Viral dynamics in HIV-1 infection. Cell 93: 665-671.

FRIEDRICH TC ET AL. 2004. Reversion of CTL escapevariant immunodeficiency viruses in vivo. Nat Med 10 275-281.

Frost SD ET AL. 2005. Neutralizing antibody responses drive the evolution of human immunodeficiency virus type 1 envelope during recent HIV infection. Proc Natl Acad Sci USA 102: 18514-18519.

Furtado GH, D'Azevedo PA, Santos AF, Gales AC, PignATARI AC AND MEdEIROs EA. 2007. Intravenous polymyxin B for the treatment of nosocomial pneumonia caused by multidrug-resistant Pseudomonas aeruginosa. Int J Antimicrob Agents 30: 315-319.
Gales AC, Menezes LC, Silbert S And SAder HS. 2003. Dissemination in distinct Brazilian regions of an epidemic carbapenem-resistant Pseudomonas aeruginosa producing SPM metallo-beta-lactamase. J Antimicrob Chemother 52: 699-702.

Goldman GH, da Silva Ferreira ME, dos Reis Marques E, Savoldi M, Perlin D, Park S, Godoy Martinez PC, Goldman MH ANd COLOMBo AL. 2004. Evaluation of fluconazole resistance mechanisms in Candida albicans clinical isolates from HIV-infected patients in Brazil. Diagn Microbiol Infect Dis 50: 25-32.

Goulder PJ ET AL. 1997. Late escape from an immunodominant cytotoxic T-lymphocyte response associated with progression to AIDS. Nat Med 3: 212-217.

HAJJEH RA ET AL. 2004. Incidence of bloodstream infections due to Candida species and in vitro susceptibilities of isolates collected from 1998 to 2000 in a populationbased active surveillance program. J Clin Microbiol 42: 1519-1527.

HENDRICKSON SL ET AL. 2008. Host Genetic Influences on Highly Active Antiretroviral Therapy Efficacy and AIDSFree Survival. J Acquir Immune Defic Syndr 48(3): 263271.

Holmes EC AND MoYA A. 2002. Is the quasispecies concept relevant to RNA viruses? J Virol 76: 460-465.

Jenkins GM, Rambaut A, Pybus OG and Holmes EC. 2002. Rates of molecular evolution in RNA viruses: a quantitative phylogenetic analysis. J Mol Evol 54: 156165 .

JONES RN. 2001. Global aspects of antimicrobial resistance among key bacterial pathogens. Results from the 19971999 SENTRY Antimicrobial Program. Clin Infect Dis 32: S81-S156.

Kanafani ZA And Perfect JR. 2008. Antimicrobial resistance: resistance to antifungal agents: mechanisms and clinical impact. Clin Infect Dis 46: 120-128.

KiJAK GH AND MCCUTChAN FE. 2005. HIV diversity, molecular epidemiology, and the role of recombination. Curr Infect Dis Rep 7(6): 480-488.

Koenig S et AL. 1995. Transfer of HIV-1-specific cytotoxic $\mathrm{T}$ lymphocytes to an AIDS patient leads to selection for mutant HIV variants and subsequent disease progression. Nat Med 1: 330-336.

Koonin EV, Senkevich TG and Dolja VV. 2006. The ancient Virus World and evolution of cells. Biol Direct 1: 29.

KRESS KD. 2004. HIV update: emerging clinical evidence and a review of recommendations for the use of highly 
active antiretroviral therapy. Am J Health Syst Pharm 61(Suppl 3): S3-14; quiz S15-16.

KUMAR A ET AL. 2006. Duration of hypotension before initiation of effective antimicrobial therapy is the critical determinant of survival in human septic shock. Crit Care Med 34: 589-596.

KURITZKeS DR. 2004. Preventing and managing antiretroviral drug resistance. AIDS Patient Care STDS 18(5): 259-273.

KURITZKES DR. 2007. HIV resistance: frequency, testing, mechanisms. Top HIV Med 15(5): 150-154.

LAGNESE M AND DAAR ES. 2008. Antiretroviral regimens for treatment-experienced patients with HIV-1 infection. Expert Opin Pharmacother 9: 687-700.

Lamaro-Cardoso J, Castanheira M, de Oliveira RM, E Silva SA, Pignatari AC, Mendes RE, Pimenta FC And Andrade AL. 2007. Carriage of methicillin-resistant Staphylococcus aureus in children in Brazil. Diagn Microbiol Infect Dis 57: 467-470.

LAURENCE J. 2008. Durability of clinical responses to antiHIV therapies. AIDS Read 18(3): 120-121.

LESLIE AJ ET AL. 2004. HIV evolution: CTL escape mutation and reversion after transmission. Nat Med 10(3): 282-289.

Levy DN, Aldrovandi GM, Kutsch O and Shaw GM. 2004. Dynamics of HIV-1 recombination in its natural target cells. Proc Natl Acad Sci USA 101: 4204-4209.

Little SJ, Frost SD, Wong JK, Smith DM, Pond SL, Ignacio CC, Parkin NT, Petropoulos CJ AND RICHMAN DD. 2008. The Persistence of Transmitted Drug Resistance among Subjects with Primary HIV Infection. J Virol 82(11): 5510-5518.

LUBER AD. 2005. Treatment strategies for highly treatmentexperienced HIV-infected patients. Expert Rev Anti Infect Ther 3: 815-823.

LUCAS GM. 2005. Antiretroviral adherence, drug resistance, viral fitness and HIV disease progression: a tangled web is woven. J Antimicrob Chemother 55: 413-416.

LuCAs GM, CHAisson RE AND MoORE RD. 1999. Highly active antiretroviral therapy in a large urban clinic: risk factors for virologic failure and adverse drug reactions. Ann Intern Med 131(2): 81-87.

Manrubia SC, Escarmis C, Domingo E AND LAZARo E. 2005. High mutation rates, bottlenecks, and robustness of RNA viral quasispecies. Gene 347: 273-282.

Martin GS, Mannino DM, Eaton S And Moss M. 2003. The epidemiology of sepsis in the United States from 1979 through 2000. N Engl J Med 348: 1546-1554.
MARTINEZ-PiCAdo J ET AL. 2000. Antiretroviral resistance during successful therapy of HIV type 1 infection. Proc Natl Acad Sci USA 97: 10948-10953.

MARTINEZ-PiCADo J ET AL. 2006. Fitness cost of escape mutations in $\mathrm{p} 24 \mathrm{Gag}$ in association with control of human immunodeficiency virus type 1. J Virol 80: 3617-3623.

McCutchan FE. 2006. Global epidemiology of HIV. J Med Virol 78(Suppl 1): S7-S12.

McCutchan Fe, Sankale JL, M'Boup S, Kim B, Tovanabutra S, Hamel DJ, Brodine SK, Kanki PJ AND BIRX DL. 2004. HIV type 1 circulating recombinant form CRF09_cpx from west Africa combines subtypes A, F, G, and may share ancestors with CRF02_AG and Z321. AIDS Res Hum Retroviruses 20: 819-826.

Mendes RE, Kiyota KA, Monteiro J, Castanheira M, Andrade SS, Gales AC, Pignatari AC AND TUFIK S. 2007. Rapid detection and identification of metallo-beta-lactamase-encoding genes by multiplex realtime PCR assay and melt curve analysis. J Clin Microbiol 45: 544-547.

METZNER KJ. 2006. Detection and significance of minority quasispecies of drug-resistant HIV-1. J HIV Ther 11: $74-81$.

Metzner KJ, Allers K, Rauch P And Harrer T. 2007. Rapid selection of drug-resistant HIV-1 during the first months of suppressive ART in treatment-naive patients. AIDS 21: 703-711.

Molla A ET AL. 1996. Ordered accumulation of mutations in HIV protease confers resistance to ritonavir. Nat Med 2(7): 760-766.

Moreira V, De Medeiros BC, Bonfim CM, Pasquini R AND DE MEdeIRos CR. 1998. Methemoglobinemia secondary to clofazimine treatment for chronic graft-versus-host disease. Blood 92: 4872-4873.

Morgan J. 2005. Global trends in candidemia: review of reports from 1995-2005. Curr Infect Dis Rep 7: 429-439.

Morris A, Marsden M, Halcrow K, Hughes es, Brettle RP, Bell JE And Simmonds P. 1999. Mosaic structure of the human immunodeficiency virus type 1 genome infecting lymphoid cells and the brain: evidence for frequent in vivo recombination events in the evolution of regional populations. J Virol 73: 8720-8731.

Nettles RE, KiefFer TL, Simmons RP, Cofrancesco J JR, Moore RD, Gallant Je, Persaud D And SILICIANO RF. 2004. Genotypic resistance in HIV-1infected patients with persistently detectable low-level viremia while receiving highly active antiretroviral therapy. Clin Infect Dis 39: 1030-1037. 
Nora T, Charpentier C, Tenaillon O, Hoede C, Clavel F and Hance AJ. 2007. Contribution of recombination to the evolution of human immunodeficiency viruses expressing resistance to antiretroviral treatment. J Virol 81: 7620-7628.

OPAR A. 2007. New HIV drug classes on the horizon. Nat Rev Drug Discov 6: 258-259.

OSTROSKY-ZEICHNER L ET AL. 2003. Antifungal susceptibility survey of 2,000 bloodstream Candida isolates in the United States. Antimicrob Agents Chemother 47: 3149-3154.

Pedroso C, Queiroz AT, Alcantara LC, Drexler JF, DiAZ RS, WEYLl N AND BRITES C. 2007. High prevalence of primary antiretroviral resistance among HIV-1infected adults and children in Bahia, a northeast state of Brazil. J Acquir Immune Defic Syndr 45: 251-253.

Perea S, Lopez-Ribot JL, KirkPATrick WR, MCATEe RK, Santillan RA, Martinez M, Calabrese D, SANGLARD D AND PATterson TF. 2001. Prevalence of molecular mechanisms of resistance to azole antifungal agents in Candida albicans strains displaying highlevel fluconazole resistance isolated from human immunodeficiency virus-infected patients. Antimicrob Agents Chemother 45: 2676-2684.

Perelson as, Neumann AU, Markowitz M, LeoNARD JM AND Ho DD. 1996. HIV-1 dynamics in vivo: virion clearance rate, infected cell life-span, and viral generation time. Science 271(5255): 1582-1586.

Peterlin BM AND Trono D. 2003. Hide, shield and strike back: how HIV-infected cells avoid immune eradication. Nat Rev Immunol 3(2): 97-107.

Pfaller MA, Diekema DJ, Gibbs DL, Newell VA, Meis JF, Gould IM, Fu W, Colombo AL AND Rodriguez-NoriegA E. 2007. Results from the ARTEMIS DISK Global Antifungal Surveillance study, 1997 to 2005: an 8.5-year analysis of susceptibilities of Candida species and other yeast species to fluconazole and voriconazole determined by CLSI standardized disk diffusion testing. J Clin Microbiol 45: 1735-1745.

PHILLIPS RE ET AL. 1991. Human immunodeficiency virus genetic variation that can escape cytotoxic $\mathrm{T}$ cell recognition. Nature 354(6353): 453-459.

PiACENTI FJ. 2006. An update and review of antiretroviral therapy. Pharmacotherapy 26: 1111-1133.

Pignatari A, Pfaller M, Hollis R, Sesso R, Leme I AND Herwald L. 1990. Staphylococcus aureus colonization and infection in patients on continuous ambulatory peritoneal dialysis. J Clin Microbiol 28: 1898-1902.
Pignatari A, Jones RN, Barrett MR, Sesso R, Leme I AND PFALLER MA. 1991. Use of antimicrobial susceptibility testing for epidemiology and the selection of oral, parenteral and topical regimens for control of CAPDassociated Staphylococcus aureus infection. J Chemother 3: $108-416$.

Price DA, Goulder PJ, Klenerman P, Sewell AK, EASTERBRook PJ, Troop M, BANGHAM CR AND PHILlLIPS RE. 1997. Positive selection of HIV-1 cytotoxic T lymphocyte escape variants during primary infection. Proc Natl Acad Sci USA 94: 1890-1895.

Rambaut A, Posada D, Crandall KA and Holmes EC. 2004. The causes and consequences of HIV evolution. Nat Rev Genet 5: 52-61.

Ribeiro RM, BONHOEFFER S AND NOWAK MA. 1998. The frequency of resistant mutant virus before antiviral therapy. AIDS 12: 461-465.

Richman DD, Wrin T, Little SJ AND Petropoulos CJ. 2003. Rapid evolution of the neutralizing antibody response to HIV type 1 infection. Proc Natl Acad Sci USA 100: 4144-4149.

Rosenthal VD ET AL. 2006. Device-associated nosocomial infections in 55 intensive care units of 8 developing countries. Ann Intern Med 145: 582-591.

Sa Filho DJ, Sanabani S, Diaz RS, Munerato P, Brunstein A, Fusuma E, SABino EC And JANini LM. 2005. Analysis of full-length human immunodeficiency virus type 1 genome reveals a variable spectrum of subtypes B and frecombinants in São Paulo, Brazil. AIDS Res Hum Retroviruses 21: 145-151.

SAder HS, Pignatari AC, Hollis RJ AND Jones RN. 1994. Evaluation of interhospital spread of methicillinresistant Staphylococcus aureus in São Paulo, Brazil, using pulsed-field gel electrophoresis of chromosomal DNA. Infect Control Hosp Epidemiol 15: 320-323.

Sader HS, Jones RN, Gales AC, Silva JB and PigNATARI AC. 2004. SENTRY antimicrobial surveillance program report: Latin American and Brazilian results for 1997 through 2001. Braz J Infect Dis 8: 25-79.

SAlgado MM, Pignatari AC AND Bellinati-Pires R. 2004. Phagocytosis and killing of epidemic methicillinresistant Staphylococcus aureus by human neutrophils and monocytes. Braz J Infect Dis 8: 80-89.

Salomao R, Wey SB, Pignatari AC and Castelo FilHo A. 1992. [Epidemiology of bacteremias at a university hospital]. Rev Assoc Med Bras 38(2): 62-66.

Salomao R, Castelo Filho A, Pignatari AC and WEY SB. 1993. Nosocomial and community acquired 
bacteremia: variables associated with outcomes. Rev Paul Med 111: 456-461.

Salomao R, Blecher S, DA-Silva M, Villins M, DASILVA EH AND Rosenthal VD. 2005. Education and performance feedback effect on rates of central vascular catheter-associated bloodstream infections in adult intensive care units in one hospital in São Paulo, Brazil. In: ProceEdings and ABstracts of the $32^{\text {nd }}$ ANNUAL Scientific Meeting of the Association for ProFESSIONALS IN INFECTION CONTROL AND EPIDEMIOLOGY, Baltimore, Maryland, USA, 64 p.

Salomao R, Blecher S, Rosenthal VD, Maretti DA Silva MA, Vilins M AND DA Silva EH. 2006. Prospective Study of the Impact of Switching From an Open IV Infusion System to a Closed System on Rates of Central Venous Catheter-Associated Bloodstream Infection in a Brazilian Hospital. SHEA Meeting, Chicago, Illinois, USA, March 18th to $21^{\text {st }}$.

Sanabani S, Neto WK, DE Sa Filho DJ, Diaz RS, Munerato P, Janini LM and Sabino EC. 2006. Full-length genome analysis of human immunodeficiency virus type 1 subtype C in Brazil. AIDS Res Hum Retroviruses 22(2): 171-176.

SANGLARD D AND OdDS FC. 2002. Resistance of Candida species to antifungal agents: molecular mechanisms and clinical consequences. Lancet Infect Dis 2(2): 73-85.

SANGlard D, Ischer $\mathrm{F}$, MONOD M AND BILle J. 1996. Susceptibilities of Candida albicans multidrug transporter mutants to various antifungal agents and other metabolic inhibitors. Antimicrob Agents Chemother 40: 2300-2305.

SCHMIT JC ET AL. 1996. Multiple drug resistance to nucleoside analogues and nonnucleoside reverse transcriptase inhibitors in an efficiently replicating human immunodeficiency virus type 1 patient strain. J Infect Dis 174: 962-968.

SCHNEIDEWIND A ET AL. 2007. Escape from the dominant HLA-B27-restricted cytotoxic T-lymphocyte response in Gag is associated with a dramatic reduction in human immunodeficiency virus type 1 replication. J Virol 81: 12382-12393.

Sesso R, Barbosa D, Leme IL, Sader H, Canziani ME, Manfredi S, Draibe S and Pignatari AC. 1998. Staphylococcus aureus prophylaxis in hemodialysis patients using central venous catheter: effect of mupirocin ointment. J Am Soc Nephrol 9: 1085-1092.

Sheehy AM, Gaddis NC, Choi JD And Malim MH. 2002. Isolation of a human gene that inhibits HIV-1 in- fection and is suppressed by the viral Vif protein. Nature 418(6898): 646-650.

Siliciano JD AND Siliciano RF. 2000. Latency and viral persistence in HIV-1 infection. J Clin Invest 106: 823825 .

Siliciano JD and Siliciano RF. 2004. A long-term latent reservoir for HIV-1: discovery and clinical implications. J Antimicrob Chemother 54: 6-9.

Siliciano RF. 1999. Reservoirs for HIV-1. Curr Infect Dis Rep 1(3): 298-304.

Silva E ET AL. 2004. Brazilian Sepsis Epidemiological Study (BASES study). Crit Care 8(4): R251-260.

Skrabal K, Saragosti S, Labernardiere JL, Barin F, Clavel F and Mammano F. 2005. Human immunodeficiency virus type 1 variants isolated from single plasma samples display a wide spectrum of neutralization sensitivity. J Virol 79: 11848-11857.

SMith DM ET AL. 2007. Long-term persistence of transmitted HIV drug resistance in male genital tract secretions: implications for secondary transmission. J Infect Dis 196: 356-360.

SMIth SM. 2004. HIV CTL escape: at what cost? Retrovirology 1: 8 .

STRIZKI J. 2008. Targeting HIV attachment and entry for therapy. Adv Pharmacol 56: 93-120.

STRYJEWSKi ME AND CHAMBERS HF. 2008. Skin and softtissue infections caused by community-acquired methicillin-resistant Staphylococcus aureus. Clin Infect Dis 46(Suppl 5): S368-377.

Sucupira MC, Caseiro MM, Alves K, Tescarollo G, Janini LM, Sabino EC, Castelo A, PAge-Shafer K AND DiAZ RS. 2007. High levels of primary antiretroviral resistance genotypic mutations and $\mathrm{B} / \mathrm{F}$ recombinants in Santos, Brazil. AIDS Patient Care STDS 21(2): $116-128$

TAYlor BS, SOBIESZCZYK ME, MCCUTCHAN FE AND HAMMER SM. 2008. The challenge of HIV-1 subtype diversity. N Engl J Med 358: 1590-15602.

Telenti A. 2005. Adaptation, co-evolution, and human susceptibility to HIV-1 infection. Infect Genet Evol 5(4): $327-334$

Toleman MA, Simm AM, Murphy TA, Gales AC, BIEDENBACH DJ, JONES RN AND WALSH TR. 2002. Molecular characterization of SPM - 1 a novel metallobeta-lactamase isolated in Latin America: report from the SENTRY antimicrobial surveillance programme. J Antimicrob Chemother 50: 673-679. 
Tortorano AM, Kibbler C, Peman J, Bernhardt H, KLINGSPOR L AND GRILlot R. 2006. Candidaemia in Europe: epidemiology and resistance. Int J Antimicrob Agents 27(5): 359-366.

Tremblay M AND WAINBERG MA. 1990. Neutralization of multiple HIV-1 isolates from a single subject by autologous sequential sera. J Infect Dis 162: 735-737.

Vossen MT, Westerhout EM, Soderberg-NAucler C AND WIERTZ EJ. 2002. Viral immune evasion: a masterpiece of evolution. Immunogenetics 54(8): 527-542.

Wei X ET AL. 2003. Antibody neutralization and escape by HIV-1. Nature 422(6929): 307-312.

Wong JK, Hezareh M, Gunthard HF, HaVlir DV, Ignacio CC, SPINA CA AND Richman DD. 1997. Recovery of replication-competent HIV despite prolonged suppression of plasma viremia. Science 278(5341): 1291-1295.
Wood E, Hogg RS, Yip B, Dong WW, Wynhoven B, Mo T, Brumme CJ, Montaner JS ANd Harrigan PR. 2005. Rates of antiretroviral resistance among HIVinfected patients with and without a history of injection drug use. AIDS 19: 1189-1195.

Zhuang J, Jetzt AE, Sun G, Yu H, Klarmann G, Ron Y, Preston BD And Dougherty JP. 2002. Human immunodeficiency virus type 1 recombination: rate, fidelity, and putative hot spots. J Virol 76: 11273-1182. 